PrZemystaw Litwiniuk, ${ }^{1}$ Marcin WiąceK ${ }^{2}$

\title{
Przekształcenie podstawy prawnej zatrudniania dyrektorów w państwowych agencjach rolnych w świetle wybranych zasad konstytucyjnych
}

\section{Wprowadzenie}

Ustrój organów polskiej administracji rolnej został wykreowany w drodze ustawodawstwa krajowego i unijnego oraz praktyki orzeczniczej ostatnich 25 lat. Stwierdzić należy, iż mógł on być uważany za utrwalony. Istotnym elementem przesądzającym o sprawności i skuteczności funkcjonowania aparatu administracji publicznej są zasoby ludzkie, przygotowujące i wdrażające rozstrzygnięcia administracyjne. Ich zgodne z prawem materialnym i proceduralnym działanie w praktyce przesądza często o stabilności linii orzeczniczej organów oraz o stopniu wypełnienia zasad postępowania administracyjnego. Na wstępie podkreślić należy, iż polska administracja rolna, przez którą autorzy niniejszego opracowania rozumieją agencje państwowe, Kasę Rolniczego Ubezpieczenia Społecznego oraz inspekcje podległe lub nadzorowane przez Ministra Rolnictwa i Rozwoju Wsi, nie została włączona w struktury korpusu służby cywilnej. Status pracowników tej administracji regulowany jest przez właściwe ustawy tworzące instytucje, zaliczane do tejże administracji. Do 2015 r. można było uznawać za regułę, że stosunki pracy prezesów tychże instytucji oraz ich zastępców, a także członków kierownictwa wyznaczonych z mocy ustawy do wydawania decyzji administracyjnych, są nawiązywane na podstawie powołania, a pozostali pracownicy - w tym kadra kierownicza średniego szczebla - na podstawie umowy o pracę. Tego rodzaju regulacja zapewniała dość stabilny rozwój zawodowy kadr niepowiązanych bezpośrednio z zapleczem politycznym aktualnego rządu oraz przyczyniała się do bezstronnego wykonywania zadań administracyjnych. 
Zgodnie z przepisami ustawy z dnia 22 grudnia 2015 r. o zmianie ustawy o ubezpieczeniu społecznym rolników oraz niektórych innych ustaw ${ }^{3}$ (dalej: „,ustawa nowelizująca") doszło do nowelizacji ustaw, regulujących zasady działalności m.in. Agencji Restrukturyzacji i Modernizacji Rolnictwa (ARiMR), Agencji Rynku Rolnego (ARR), Agencji Nieruchomości Rolnych (ANR) i Kasy Rolniczego Ubezpieczenia Społecznego (KRUS) poprzez przekształcenie ex lege z dniem opublikowania ustawy nowelizującej umownych stosunków pracy kierownictwa średniego szczebla na nawiązane na podstawie powołania. Celem niniejszego artykułu jest ocena zgodności zmian wprowadzonych do ww. ustaw regulujących podstawy i sposób nawiązywania stosunków pracy z kadrą kierowniczą polskiej administracji rolnej z postanowieniami art. 2, 24, 30 i 60 Konstytucji Rzeczpospolitej Polskiej, w szczególności w świetle zasady zaufania obywatela do państwa, zasady ochrony pracy, zasady poszanowania godności człowieka i równego dostępu do służby publicznej. Niniejsze opracowanie stanowi analizę zgodności niektórych przepisów ustawy o zmianie ustawy o ubezpieczeniu społecznym rolników i niektórych innych ustaw z ww. wzorcami konstytucyjnymi.

\section{Ustawa nowelizująca}

Ustawa nowelizująca, którą ogłoszono 11 stycznia 2016 roku, wprowadziła zmiany do ustawy z dnia 20 grudnia 1990 r. o ubezpieczeniu społecznym rolników, ${ }^{4}$ ustawy z dnia 19 października 1991 r. o gospodarowaniu nieruchomościami rolnymi Skarbu Państwa, ${ }^{5}$ ustawy z dnia 21 grudnia 2000 r. o jakości handlowej artykułów rolno-spożywczych, ${ }^{6}$ ustawy z dnia 18 grudnia 2003 r. o ochronie roślin, ${ }^{7}$ ustawy z dnia 29 stycznia 2004 r. o Inspekcji Weterynaryjnej, ${ }^{8}$ ustawy z dnia 11 marca 2004 r. o Agencji Rynku Rolnego i organizacji niektórych rynków rolnych, ${ }^{9}$ ustawy z dnia 22 października 2004 r. o jednostkach doradztwa rolniczego ${ }^{10}$ oraz ustawy z dnia 9 maja 2008 r. o Agencji Restrukturyzacji i Modernizacji Rolnictwa. ${ }^{11}$

Najistotniejsze zmiany wprowadzone ustawą nowelizującą dotyczą sytuacji prawnej pracowników ANR, ARiMR, ARR i KRUS. Instytucje te utworzone na początku lat dziewięćdziesiątych XX w. zatrudniają obecnie ponad 20000 osób na terenie całego kraju. Od 19 sierpnia 2005 roku, na mocy przepisów ustawy z dnia 17 czerwca 2005 r. o zmianie ustawy o służbie cywilnej oraz niektórych innych

\footnotetext{
Dz.U. z 2016 r. poz. 50.

Dz.U. z 2016 r. poz. 277

Dz.U. z 2016 r. poz. 1491

Dz.U. z 2016 r. poz. 1604

Dz.U. z 2016 r. poz. 17.

Dz.U. z 2016 r. poz. 1077

Dz.U. z 2016 r. poz. 401.

Dz.U. z 2016 r. poz. 356.

Dz.U. z 2016 r. poz. 1512
} 
ustaw $^{12}$, pracowników tych instytucji zatrudnia się po przeprowadzeniu naboru, zorganizowanego z zachowaniem zasad otwartości o konkurencyjności. ${ }^{13}$ Jak podkreślano w literaturze, „obie te zasady - jak również zasada jawności, łącząca się ściśle z otwartością naboru - realizują określoną wizję administracji publicznej zadekretowaną w art. 60 i 153 ustawy zasadniczej. Zgodnie z art. 60 Konstytucji RP obywatele polscy korzystający z pełni praw publicznych mają prawo dostępu do służby publicznej na jednakowych zasadach. Z kolei w art. 153 Konstytucji RP określono główne cele i wartości, jakie przyświecały powołaniu do życia służby cywilnej, którymi są zawodowe, rzetelne, bezstronne i politycznie neutralne wykonywanie zadań państwa (...). Z jednej strony, prawo równego dostępu do służby publicznej musi uwzględniać dwa podstawowe aspekty - jawność procedur naboru oraz sprawiedliwe dla wszystkich mechanizmy rekrutacji. Z drugiej strony, rzetelność i profesjonalizm kadr administracyjnych zależy w dużej mierze, choć nie tylko, od jakości pozyskiwanych kandydatów do służby, stąd bardzo ważną rolę odgrywają obiektywne i merytoryczne kryteria selekcji kandydatów". ${ }^{14}$

Należy wskazać, że przed wejściem w życie ustawy nowelizującej, prezesi państwowych agencji rolnych oraz KRUS byli powoływani po przeprowadzeniu otwartego i konkurencyjnego naboru przez Prezesa Rady Ministrów, a zastępcy prezesa przez ministra rolnictwa i rozwoju wsi (lub - jak w przypadku ARiMR - przez prezesa agencji), jednakże z kadrą kierowniczą średniego szczebla stosunek pracy nawiązywano na podstawie umowy o pracę. W świetle przepisów prawa pracy stosunek pracy nawiązany na podstawie umowy o pracę na czas nieokreślony charakteryzuje się większą stabilnością, a wypowiedzenie umowy lub jej warunków, a także rozwiązanie umowy bez zachowania okresu wypowiedzenia, wymaga podania rzeczywistej i konkretnej przyczyny. Nadto, pracownik, z którym rozwiązano umowę o pracę z naruszeniem przepisów prawa, może wnosić przed sądem pracy o przywrócenie do pracy, co w przypadku pracowników zatrudnionych na podstawie powołania jest niedopuszczalne.

Zgodnie z art. 1 pkt 3 lit. a) ustawy nowelizującej art. 60 ust. 1 ustawy z dnia 20 grudnia 1990 r. o ubezpieczeniu społecznym rolników otrzymał brzmienie: „Prezes Kasy powołuje i odwołuje kierowników komórek organizacyjnych w centrali, oddziałach regionalnych i placówkach terenowych, o których mowa w art. 61 ust. 1 pkt 1-3, a pozostałych pracowników zatrudnia na podstawie umowy o pracę, chyba że odrębne przepisy wymagają zatrudnienia na podstawie powołania."

Podobnie, art. 2 pkt 1 lit. b) ustawy nowelizującej stanowi, że w ustawie z dnia 19 października 1991 r. o gospodarowaniu nieruchomościami rolnymi Skarbu Pań-

12 Dz.U. z 2005 r. Nr 132, poz. 1110.

13 Omawiana ustawa dokonała zmian właściwych ustaw: art. 3 dotyczył KRUS, art. 5 - ANR, art. 6 - ARiMR, art. 17 - ANR.

14 Komentarz do ustawy o służbie cywilnej, [w:] „Prawo urzędnicze. Komentarz”, K.W. Baran (red.), Lex 2014. 
stwa, w art. 9 po ust. 3 dodaje się ust. $3 \mathrm{a}$ w brzmieniu: „Prezes Agencji powołuje i odwołuje kierowników komórek organizacyjnych w Biurze Prezesa i ich zastępców, głównego księgowego oraz dyrektorów i zastępców dyrektorów oddziałów terenowych Agencji."

Z kolei, art. 6 pkt 1 lit. a) ustawy nowelizującej wprowadził zmianę do ustawy z dnia 11 marca 2004 r. o Agencji Rynku Rolnego i organizacji niektórych rynków rolnych, poprzez nadanie art. 6 ust. 3 następującego brzmienia: „Prezes Agencji kieruje działalnością Agencji przy pomocy zastępców Prezesa Agencji oraz dyrektorów oddziałów terenowych. Zastępców Prezesa Agencji powołuje minister właściwy do spraw rynków rolnych na wniosek Prezesa Agencji. Minister właściwy do spraw rynków rolnych odwołuje zastępców Prezesa Agencji. Prezes Agencji powołuje i odwołuje kierowników komórek organizacyjnych w Centrali i ich zastępców oraz dyrektorów oddziałów terenowych i ich zastępców."

Także art. 8 pkt 2 lit. a) ustawy z dnia 22 grudnia 2015 r. ustawy nowelizującej zmienił brzmienie art. 9 ust. 3 ustawy z dnia 9 maja 2008 r. o Agencji Restrukturyzacji i Modernizacji Rolnictwa na następujące: „Kierowników komórek organizacyjnych w Centrali Agencji i ich zastępców oraz dyrektorów oddziałów regionalnych i ich zastępców powołuje i odwołuje Prezes Agencji, a kierowników biur powiatowych i ich zastępców - dyrektor oddziału regionalnego".

Jak stanowi art. 9 ust. 2 pkt 8 ustawy nowelizującej, stosunki pracy pracowników zatrudnionych w dniu wejścia w życie ustawy na stanowiskach, o których mowa w znowelizowanych przepisach ww. ustaw, „stają się stosunkami pracy na podstawie powołania w rozumieniu przepisów ustawy z dnia 26 czerwca $1974 \mathrm{r}$. - Kodeks pracy”. Należy wskazać, że tego rodzaju stosunki należą do najmniej stabilnych i wiążą się z możliwością ich arbitralnego rozwiązania bez podania przyczyny w każdym czasie przez pracodawcę. Ustawa nowelizująca z dnia 22 grudnia 2015 r. weszła w życie z dniem ogłoszenia, a więc 11 stycznia 2016 r. $^{15}$

Celem ustawodawcy, ujawnionym w uzasadnieniu projektu ustawy, była potrzeba „uelastycznienia powoływania i odwoływania” osób na stanowiskach objętych działaniem ustawy, ${ }^{16} \mathrm{z}$ czego organy ARiMR, ANR, ARR i KRUS skorzystały rozwiązując poprzez odwołanie ze stanowiska stosunki pracy z absolutną większością osób na nich zatrudnionych. W projekcie ustawy nowelizującej nie wskazano jakiejkolwiek innej intencji projektodawcy. W ten eufemistyczny sposób ustawodawca wprost przyznał, że jedynym jego zamierzeniem nie są reformy ustroju państwa czy ustroju organów administracji publicznej, lecz szybkie wprowadzenie zmian kadrowych w niektórych organach. Zatem, wskazane wyżej przepisy ustawy

15 Zob. art. 10 ustawy nowelizującej.

16 Zob. projekt ustawy o zmianie ustawy o ubezpieczeniu społecznym rolników oraz niektórych innych ustawy, druk $\mathrm{nr} 121$. 
nowelizującej doprowadziły do tego, że - ze skutkiem natychmiastowym, bez jakiegokolwiek okresu przejściowego - stosunki pracy osób zatrudnionych w agencjach i Kasie objętych reżimem ustawy, zostały przekształcone ze stosunku pracy na podstawie umowy o pracę w stosunek pracy na podstawie powołania w rozumieniu przepisów Kodeksu pracy. Doprowadziło to do pozbawienia tych osób dotychczasowych gwarancji stabilności zatrudnienia w szczególności w zakresie przesłanek umożliwiających rozwiązanie stosunku pracy przez pracodawcę. Treść stosunku pracy ww. osób została ustawowo zmodyfikowana w ten sposób, że względnie stabilny stosunek pracy oparty na umowie o pracę został - z mocy prawa - przekształcony w najbardziej nietrwałą formę zatrudnienia. Co więcej, wszystkie objęte ustawą nowelizująca stanowiska pracy zostały wyłączone ze stosowania procedury otwartego i konkurencyjnego naboru, co znacznie ograniczyło zastosowanie omówionej wyżej zasady, wynikającej z art. 60 Konstytucji RP.

\section{Zasada zaufania obywatela do państwa i stanowionego przez nie prawa}

Zgodnie z orzecznictwem Trybunału Konstytucyjnego (TK) ,zasada ochrony zaufania obywatela do państwa i prawa, określana także jako zasada lojalności państwa wobec obywatela, wyraża się w takim stanowieniu i stosowaniu prawa, by nie stawało się ono swoistą pułapką dla obywatela i aby mógł on układać swoje sprawy w zaufaniu, iż nie naraża się na prawne skutki, których nie mógł przewidzieć w momencie podejmowania decyzji i działań, oraz w przekonaniu, iż jego działania podejmowane zgodnie z obowiązującym prawem będą także w przyszłości uznawane przez porządek prawny. Przyjmowane przez ustawodawcę nowe unormowania nie mogą zaskakiwać ich adresatów, którzy powinni mieć czas na dostosowanie się do zmienionych regulacji i spokojne podjęcie decyzji co do dalszego postępowania". ${ }^{17}$ Z kolei w wyroku z dnia 14 czerwca 2000 r., sygn. akt P 3/00, Trybunał stwierdził, że ,zasada zaufania obywatela do państwa i stanowionego przez nie prawa opiera się na pewności prawa, a więc na takim zespole cech przysługujących prawu, które zapewniają jednostce bezpieczeństwo prawne; umożliwiają jej decydowanie o swoim postępowaniu w oparciu o pełną znajomość przesłanek działania organów państwowych oraz konsekwencji prawnych, jakie jej działania mogą pociągnąć za sobą. Jednostka winna mieć możliwość określenia zarówno konsekwencji poszczególnych zachowań i zdarzeń na gruncie obowiązującego w danym momencie systemu, jak też oczekiwać, że prawodawca nie zmieni ich w sposób arbitralny. Bezpieczeństwo prawne jednostki związane z pewnością prawa, umożliwia więc przewidywalność działań organów państwa, a także prognozowanie działań własnych”. 


\section{Zasada ochrony pracy}

W omawianym zagadnieniu, zasada zaufania obywatela do państwa i stanowionego przez nie prawa, wynikająca $\mathrm{z}$ art. 2 Konstytucji, pozostaje w ścisłym związku z zasadą ochrony pracy, wynikającą z art. 24 Konstytucji („Praca znajduje się pod ochroną Rzeczypospolitej Polskiej. Państwo sprawuje nadzór nad warunkami wykonywania pracy”). Jak przyjmuje się w orzecznictwie TK, „z zasady zawartej w art. 24 Konstytucji wynika obowiązek stwarzania przez państwo gwarancji ochrony pracowników, w tym ochrony przed niezgodnymi z prawem lub nieuzasadnionymi działaniami pracodawcy, oraz kontroli przestrzegania przepisów prawa pracy". ${ }^{18}$ W świetle powyższego przepisu „na państwie ciąży obowiązek ochrony pracowników jako «słabszej» strony stosunku pracy, a w konsekwencji obowiązek stwarzania przez państwo gwarancji prawnych ochrony, w tym ochrony przed niezgodnymi z prawem bądź nieuzasadnionymi działaniami pracodawców". ${ }^{19}$ Należy dodatkowo podkreślić, że osoby objęte omawianymi przepisami były pracownikami państwowymi. W sytuacji gdy państwo występuje - z jednej strony - jako pracodawca oraz - z drugiej strony - jako ustawodawca staje się w ten sposób szczególnie „silną”, w porównaniu do innych pracodawców, stroną stosunku pracy w relacji do pracownika. Zasada zaufania obywatela do państwa oraz zasada ochrony pracy powinny być w takich przypadkach respektowane w sposób kwalifikowany. ${ }^{20}$

\section{Zasada ochrony godności człowieka}

Ponadto z orzecznictwa TK wynika, że art. 24 Konstytucji powinien być interpretowany w związku z zasadą ochrony godności człowieka. ${ }^{21}$ Zdaniem TK ,zachowanie przyrodzonej i niezbywalnej godności człowieka nakazuje bowiem przyjąć regułę stanowienia i interpretacji prawa, która zakazywać będzie arbitralnego traktowania pracownika jako przedmiotu pracy, a przypisywać mu będzie pozycję jej twórczego podmiotu". ${ }^{22}$

\section{Ochrona trwałości stosunku pracy w służbie publicznej}

Z orzecznictwa TK wynika, że modyfikacja treści stosunku pracy przez ustawodawcę - a niekiedy nawet wygaszenie tego stosunku ex lege w odniesieniu do pewnej kategorii pracowników - nie jest bezwzględnie wykluczona przez Konstytucję. Ustawodawca ,musi jednak posługiwać się adekwatnymi instrumentami prawnymi, aby nie doprowadzić do faktycznego zniesienia wszelkich gwarancji ochronnych przynależnych pracy oraz wykonującym ją podmiotom niezależnie od rodzaju oraz

Wyrok TK z dnia 4 października 2005 r., sygn. akt K 36/03.

Wyrok TK z dnia 18 października 2005 r., sygn. akt SK 48/03.

Por. wyrok TK z dnia 21 marca 2005 r., sygn. akt P 5/04.

Art. 30 Konstytucji RP.

Wyrok TK z dnia 14 czerwca 2011 r., sygn. akt Kp 1/11. 
formy zatrudnienia. Dotyczy to przede wszystkim tych mechanizmów wykorzystywanych przez ustawodawcę, które ingerują w stabilizację stosunku pracy urzędników realizujących zadania związane z obsługą administracyjną państwa" ${ }^{23}$

Ponadto Trybunał w swoim orzecznictwie podkreślał, że „ochrona trwałości stosunku pracy w służbie publicznej pełni szereg funkcji, stanowiąc szczególnie ważny instrument polityki zatrudnienia w tej służbie. Została zagwarantowana tym osobom, które posiadają odpowiednie kwalifikacje i kompetencje określone w ustawie. Ma ona na celu zapewnienie instytucjom państwowym odpowiedniej liczby wysoko wykwalifikowanych pracowników. Stabilność zatrudnienia uniezależnia obsadzanie stanowisk w służbie publicznej od kryteriów politycznych i stanowi konieczny warunek bezstronności politycznej i kompetencji tej służby. Ważnym czynnikiem w służbie publicznej jest doświadczenie zawodowe. Ochrona trwałości stosunku pracy sprzyja wykorzystaniu doświadczenia zawodowego urzędników państwowych. Ostatecznym celem stabilności zatrudnienia w służbie publicznej jest zagwarantowanie obywatelom prawa do dobrej administracji. Z kolej z punktu widzenia sytuacji prawnej jednostek poczucie stabilności zatrudnienia stanowi jedną z przesłanek kierowania swoimi sprawami życiowymi i zachęca m.in. do doskonalenia swoich umiejętności zawodowych stosownie do perspektyw awansu w służbie publicznej, bardziej niż z myślą o konieczności dostosowywania swoich kwalifikacji do zmian rynku pracy". ${ }^{24}$

$\mathrm{Z}$ orzecznictwa TK płynie wniosek, że modyfikacje w zakresie stosunku pracy osób pełniących funkcje publiczne mogą być uzasadnione w warunkach szerszej reformy administracji publicznej, a ponadto ustawodawca powinien zapewnić pracownikom, których treść stosunku pracy ulega zmianom, czas na dostosowanie się do nowej sytuacji.

\section{Wątpliwości konstytucyjne}

Biorąc pod uwagę wyżej opisane zasady konstytucyjne, analizowane przepisy ustawy nowelizującej z dnia 22 grudnia 2015 r. budzą wątpliwości w zakresie zgodności z art. $2 \mathrm{i}$ art. $24 \mathrm{w}$ zw. $\mathrm{z}$ art. 30 Konstytucji RP przede wszystkim z tego powodu, że naruszają zaufanie osób, które pełniły wskazane tam funkcje, do względnej trwałości stosunku pracy, wynikającego z umowy o pracę. Podejmując zatrudnienie, osoby takie powinny były co prawda zdawać sobie sprawę, że w przyszłości treść ich stosunku pracy może ulec pewnym zmianom, jednak zmiany takie nie będą wprowadzone bez uzasadnienia merytorycznego i bez okresu przejściowego. 
Co więcej, w analizowanym stanie rzeczy, pracodawcą jest państwo, co dawało pracownikom podstawę do szczególnego poczucia bezpieczeństwa prawnego oraz zaufania do tego, że stosunek pracy nie zostanie zniesiony czy przekształcony w sposób arbitralny. Tymczasem zakwestionowane przepisy nie są związane z jakąkolwiek reformą administracji publicznej, która mogłaby uzasadniać zastosowanie tego typu środków. Ich celem było umożliwienie szybkiej zmiany personalnej na stanowiskach kierowniczych w niektórych organach administracji publicznej.

Adresaci zakwestionowanych regulacji, podejmując pracę w służbie publicznej, mogli oczekiwać od państwa, że nie dokona nagłych zmian, przekreślających stabilność zatrudnienia oraz narażających osoby, które tej służbie się poświęciły, na utratę pracy z dnia na dzień. Państwo jest wszak związane zasadą zaufania obywatela do państwa i stanowionego przez nie prawa, ${ }^{25}$ a więc powinno być szczególnie lojalnym i przewidywalnym pracodawcą. Adresaci zakwestionowanych regulacji mogli zatem układać swoje plany życiowe w oparciu o założenie, że ich stosunek pracy nie będzie mógł zostać rozwiązany z dnia na dzień, z pominięciem gwarancji zawartych w Kodeksie pracy. Nowelizacja unicestwiła tak rozumiane zaufanie, stanowiąc zaskoczenie dla jej adresatów, którzy - bez okresu przejściowego, z dniem wejścia w życie ustawy - stali się ex lege pracownikami zatrudnionymi na podstawie powołania, a więc najmniej trwałej postaci stosunku pracy, na co się nie godzili podejmując zatrudnienie.

Również z punktu widzenia zasady ochrony godności człowieka, ${ }^{26}$ która powinna być uwzględniana przy interpretacji zasady ochrony pracy, ${ }^{27}$ należy dostrzec, że ustawodawca potraktował pracowników w sposób instrumentalny. Z przyczyn niemotywowanych ważnym interesem publicznym pracownicy zostali pozbawieni w sposób natychmiastowy gwarancji ochronnych wynikających z Kodeksu pracy i od dnia ogłoszenia ustawy, bez okresu vacatio legis, mogli zostać w każdej chwili odwołani, bez podawania przyczyn.

Analizowane przepisy ustawy nowelizującej doprowadziły do pozbawienia adresatów ustawy gwarancji stabilności zatrudnienia w zakresie przesłanek umożliwiających rozwiązanie stosunku pracy. Względnie stabilny stosunek pracy oparty na umowie o pracę został - z mocy prawa, bez odpowiedniego okresu dostosowawczego - przekształcony w najbardziej nietrwałą formę zatrudnienia.

W konsekwencji art. 9 ust. 2 pkt 8 w zw. z art. 1 pkt 3 lit. a), art. 2 pkt 1 lit. b), art. 6 pkt 1 lit. a), art. 8 pkt 2 lit. a) i pkt 3 oraz w zw. z art. 10 ustawy nowelizującej z dnia 22 grudnia 2015 r. mogą być niezgodne z art. 2 i art. 24 w zw. z art. 30 Konstytucji RP, naruszając zaufanie osób, które pełniły wskazane w tych przepi- 
sach funkcje, do zagwarantowanej przez państwo względnej trwałości stosunku pracy, wynikającej z umowy o pracę. Mimo że podejmując zatrudnienie, osoby takie powinny były zdawać sobie sprawę, że w przyszłości treść ich stosunku pracy może ulec pewnym zmianom, jednak zmiany takie nie mogą być wprowadzone bez uzasadnienia merytorycznego, bez okresu przejściowego i regulacji pozwalających adresatom norm na dostosowanie się do nowej sytuacji prawnej.

Z punktu widzenia sytuacji prawnej jednostek ,poczucie stabilności zatrudnienia stanowi jedną z przesłanek kierowania swoimi sprawami życiowymi i zachęca m.in. do doskonalenia swoich umiejętności zawodowych stosownie do perspektyw awansu w służbie publicznej, bardziej niż z myślą o konieczności dostosowywania swoich kwalifikacji do zmian rynku pracy". ${ }^{28}$

Przepisy ustawy nowelizującej z dnia 22 grudnia 2015 r. doprowadziły do instrumentalnego potraktowania pracowników - ludzi od lat poświęconych służbie państwowej. Bez uzasadnienia merytorycznego ustawodawca ex lege zmienił podstawę stosunku pracy osób zatrudnionych w omawianych agencjach wyłącznie po to, aby umożliwić ich natychmiastowe odwołanie z pominięciem regulacji ochronnych zawartych w Kodeksie pracy. Za takim rozwiązaniem nie przemawiał żaden cel znajdujący uzasadnienie w potrzebie ochrony czy realizacji wartości konstytucyjnych. Sytuacja ta może być rozpatrywana jako naruszenie konstytucyjnej zasady ochrony pracy.

\section{Instrumenty ochrony prawnej}

Jedynym, co do zasady, instrumentem ochrony prawnej, który może zastosować odwołany ze stanowiska pracownik administracji rolnej, jest wniesienie odwołania do sądu pracy, o którym mowa w art. 44 Kodeksu pracy. Jednakże sądy powszechne nie dysponują uprawnieniem do samodzielnej kontroli konstytucyjności przepisów ustaw, na podstawie których orzekają, co w normalnym toku procesu prowadzi do oddalenia powództwa. Dlatego pod rozwagę powinny być wzięte dwie koncepcje ochrony praw powoda: przedstawienie przez sąd orzekający w toku procesu pytania prawnego Trybunałowi Konstytucyjnemu (art. 193 Konstytucji), albo wystąpienie przez powoda, którego powództwo oddalono w obu instancjach postępowania przed sądem pracy, ze skargą konstytucyjną (art. 79 Konstytucji). W każdym przypadku przedmiotem postępowania przed Trybunałem Konstytucyjnym będzie rozstrzygnięcie kwestii, czy wskazane powyżej przepisy ustawy z dnia 22 grudnia 2015 r. o zmianie ustawy o ubezpieczeniu społecznym rolników oraz niektórych innych ustaw są zgodne z zasadą zaufania obywatela do państwa i stanowionego przez nie 
prawa, wynikającą z art. 2 Konstytucji RP, a także z art. 24 (zasada ochrony pracy) w zW. z art. 30 (zasada ochrony godności człowieka) Konstytucji RP?

Stwierdzić należy, że sądy powszechne dość niechętnie korzystają z instytucji pytania prawnego. Przedstawienie Trybunałowi Konstytucyjnemu pytania prawnego przez sąd wchodzi w rachubę, gdy to sąd, a nie wyłącznie strona, poweźmie wątpliwości co do zgodności aktu prawnego z Konstytucją RP. ${ }^{29}$ Podobne stanowisko wyraził Sąd Rejonowy dla Warszawy-Śródmieścia w Warszawie, który w sprawie o sygn. akt VIII P 195/16 odmówił przedstawienia TK pytania prawnego w sprawie zgodności z ustawą zasadniczą omawianej w niniejszym opracowaniu ustawy. Sąd doszedł do wniosku i wyeksponował w uzasadnieniu wyroku z dnia 29 czerwca 2016 r., iż ,prawodawca może nowelizować obowiązujące prawo, także na niekorzyść obywateli, pogarszając ich sytuację prawną. Jednakże musi respektować wymogi konstytucyjne. Nowelizacja przepisów per se, nawet wówczas, gdy pogarsza sytuację obywatela, nie przesądza automatycznie o naruszeniu zasady zaufania do państwa i stanowionego przez nie prawa, musi być jednak zapewniony odpowiedni okres dostosowawczy i zapewnione respektowanie praw słusznie nabytych". Sąd, biorąc pod uwagę powyższy aspekt, przypomniał, iż ,TK zwracał także uwagę, że z zasady ochrony zaufania obywateli do państwa i stanowionego przez nie prawa nie wynika, że każdy może ufać, iż sposób unormowania jego praw i obowiązków nigdy nie ulegnie zmianie na niekorzyść; niemniej ostateczna ocena regulacji prawnych zależy od treści dokonywanych przez prawodawcę zmian, a nade wszystko od sposobu ich wprowadzenia, przy uwzględnieniu całokształtu okoliczności oraz konstytucyjnego systemu wartości.” Sąd wskazał nadto, iż „reforma ustroju państwa, w tym ustroju administracji publicznej, dotyczy samych fundamentów ładu publicznego w państwie; w takim przypadku istnieją wystarczająco silne argumenty przemawiające za odstąieniem od zasady stabilności i pewności prawa. Zmiana warunków społecznych lub gospodarczych może wymagać zmian regulacji prawnych, w tym również zmian, które dotyczą nawiązywania i rozwiązywania stosunków pracy”. Sąd, podając motywy wydania orzeczenia, podniósł, że „dokonywane zmiany regulacji prawnych zawartych w różnego rodzaju aktach zmierzających do dokonania przekształceń ustrojowych, w tym również takich, które dotyczą reformowania administracji publicznej, nie mogą pozostawać bez wpływu na ukształtowanie indywidualnych stosunków prawnych obywateli, w tym tych o charakterze pracowniczym, o czym wspomniał TK w wyroku z dnia 18 lutego 2003 r. w sprawie K 24/02 uznając demokratyczne prawo legitymowanego ustawodawcy do przeprowadzania reform ustrojowych w konstytucyjnie określonych granicach. Uznanie takich zmian za konstytucyjnie wykluczoną ingerencję ustawodawcy oznaczałoby, 
że władza publiczna nie może przeprowadzić zmian ustrojowych połączonych z likwidacją i tworzeniem nowych stanowisk pracowniczych”. Sąd Rejonowy wskazał także, że ,kwestionowana ustawa sama w sobie nie spowodowała automatycznego rozwiązania stosunku pracy, a jedynie zmieniła podstawę już nawiązanego stosunku pracy (...)".

Trudno aprobująco odnieść się do argumentacji przedstawionej w wyżej omawianym uzasadnieniu orzeczenia. $\mathrm{Z}$ zasady sprawiedliwej procedury oraz prawa do sądu i rzetelnego procesu (art. 45 ust. 1 Konstytucji) ${ }^{30}$ wynika obowiązek sądu wszechstronnego odniesienia się do zarzutu niekonstytucyjności przepisu, na którym ma zostać oparte orzeczenie. Natomiast skład orzekający nie odniósł się w ogóle do wątpliwości konstytucyjnych dotyczących przepisów ustawy nowelizującej w zakresie ich zgodności z art. 24 Konstytucji, który należy wykładać z uwzględnieniem treści art. 30 ustawy zasadniczej, wyrażającymi zasadę ochrony pracy oraz zasadę ochrony godności człowieka. Jak wyżej przywoływano, w uzasadnieniu wyroku zawarte są wywody odnoszące się wyłącznie do art. 2 Konstytucji i wynikającej z tego przepisu zasady zaufania obywatela do państwa i stanowionego przez nie prawa. Sąd przy tym nie wskazał, powołując się na orzecznictwo trybunalskie, na okoliczność prowadzenia jakiejkolwiek reformy administracji publicznej, której elementem miała być analizowana ustawa nowelizująca.

Jeśli inne sądy podzieliłyby przedstawione wyżej stanowisko Sądu Rejonowego, to wówczas instytucja pytania prawnego może okazać się nieużyteczna w procedurze dochodzenia roszczeń pracowniczych, związanych z faktem rozwiązania stosunku pracy z zastosowaniem kwestionowanych przepisów. Byłaby to sytuacja wątpliwa z punktu widzenia zasady rzetelnego postępowania sądowego. Pytanie prawne bowiem to najpewniejsza i najskuteczniejsza forma realizacji postulatu, zgodnie z którym wyrok sądu powinien być oparty na podstawie prawnej nienaruszającej regulacji konstytucyjnych. W przeciwnym bowiem razie prawomocny wyrok może być obarczony wątpliwościami konstytucyjnymi.

Nieefektywna może okazać się również procedura skargi konstytucyjnej na podstawie art. 79 ust. 1 Konstytucji RP. Wszak kwestionowane na wstępie przepisy ustawy nowelizującej budzą wątpliwości - jak wykazano - co do zgodności z art. 2 i art. 24 Konstytucji. Z tych przepisów Konstytucji nie wynikają jednak wprost wolności czy prawa podmiotowe jednostek, lecz tzw. zasady konstytucyjne - zasada zaufania obywatela do państwa i stanowionego przez nie prawa oraz zasada ochrony pracy. W konsekwencji co do zasady niedopuszczalna jest skarga konstytucyjna oparta na tego typu zarzutach. 
Ponadto skarga konstytucyjna może być wniesiona dopiero po uzyskaniu prawomocnego wyroku, podlega długotrwałej procedurze tzw. wstępnej kontroli, a uwzględnienie podniesionych w niej zarzutów nie prowadzi do udzielenia skarżącemu natychmiastowej ochrony prawnej. Konieczne jest bowiem wszczęcie kolejnego postępowania - tj. postępowania wznowieniowego na podstawie art. 190 ust. 4 Konstytucji i wykonujących ten przepis regulacjach ustawowych.

\section{Podsumowanie}

Powyższe rozważania prowadzą do konkluzji, iż przepisy analizowane w niniejszym artykule wymagają weryfikacji przed Trybunałem Konstytucyjnym, z tym że najskuteczniejszą formą przedstawienia ich do procedury kontroli hierarchicznej zgodności norm jest pytanie prawne sądu lub tzw. abstrakcyjny wniosek uprawnionego podmiotu (np. Rzecznika Praw Obywatelskich, ogólnokrajowego organu związku zawodowego - zob. art. 191 ust. 1 Konstytucji). Wydanie orzeczenia stwierdzającego niekonstytucyjność dokonanego przekształcenia umownych stosunków pracy w nawiązane na podstawie powołania, stanowiłoby podstawę do wznowienia postępowań sądowych wszczętych z powództwa pracowników odwołanych z zajmowanych stanowisk.

Brak zbadania zgodności z Konstytucją kwestionowanych przepisów i przedstawienia przez władzę sądowniczą oceny przyjętych przez ustawodawcę rozwiązań, ośmiela do projektowania kolejnych budzących wątpliwości przepisów przekształcających umowne stosunki pracy szeregowych urzędników w stosunki pracy nawiązane na podstawie powołania, a nawet do ich wygaszania z mocy prawa. ${ }^{31}$ Dlatego sprawą zasadniczą dla dziesiątek tysięcy pracowników polskiej administracji rolnej jest wyznaczenie granicy ingerencji ustawodawcy w treść stosunków pracy pracowników służby publicznej. 
THE TRANSFORMATION OF THE LEGAL BASIS FOR HIRING DIRECTORS

IN STATE AGRICULTURAL AGENCIES IN THE LIGHT OF SELECTED

CONSTITUTIONAL PRINCIPLES

Keywords: state agricultural agencies, rules for hiring management staff, amendment to the law on social insurance for farmers

The purpose of this article is to assess the compatibility of the amendments made to the laws regulating the basis and manner of establishing working relationships with the management staff of agricultural administration in Poland with the provisions of art. 2, 24, 30 and 60 of the Constitution of the Republic of Poland, in particular in the light of the principle of citizens' trust in the State, the rules of protection of labour, the principle of respect for and protection of human dignity and the principle of equal access to public service.

The elaboration is an analysis of the compatibility of certain provisions of the Act of 22 December 2015 on the Amendment to the Act on Social Insurance for farmers and to certain other laws with the aforesaid constitutional models.

Bibliografia:

Baran K. W. (red.), Prawo urzędnicze. Komentarz, Lex 2014.

Wiącek M., Pytanie prawne sądu do Trybunału Konstytucyjnego, Warszawa 2011. 